\title{
DETERMINANTS OF NON-PERFORMING LOANS IN PAKISTAN
}

\author{
Tanweer Ul Islam ${ }^{1}$
}

Faiza Zafar ${ }^{\mathrm{b}}$, Naimal Fatima ${ }^{\mathrm{b}}$, Nayab Tahir ${ }^{\mathrm{b}}$

\begin{abstract}
Many countries have been facing the problem of bank insolvency across the globe. Asset deterioration is one of the main reasons for insolvency of banks. The objective of the paper is to ascertain the determinants of nonperforming loans (NPLs) in the banking sector of Pakistan for the period 2006-16. Other than the bank specific and macro variables proposed by the literature, the roles of weighted maturity and output gap are for the first time examined. We find significant impact of output gap on NPLs however weighted maturity has insignificant role in shaping the future NPLs. Bank specific drivers of NPLs include bank size and capital adequacy ratio.
\end{abstract}

Key words: Business fluctuations, financial stability, output gap, and weighted maturity

JEL Classification: C23, C54, E32, G24

\footnotetext{
${ }^{1}$ Assistant Professor, Department of Economics, National University of Sciences \& Technology, Islamabad. Email: tanweer@s3h.nust.edu.pk

${ }^{\mathrm{b}}$ Graduate, Department of Economics, National University of Sciences \& Technology, Islamabad.
} 


\section{Introduction}

Banks play a vital role for the economy and act as intermediary between depositors and borrowers. The expansion of the financial sector is a step closer to the development of an economy hence making it a key factor in growth. The financial crisis of 2007-08 was a major setback for the global economy and put them at a financial risk upsetting the credit quality of loan portfolios across the globe (Dimitrios, Helen, \& Mike, 2016). Pakistan's banking sector is facing the problem of nonperforming loans for the last three to four decades. Pakistan's banks had crossed the 14 percent limit of NPLs to gross advances in 2010-11, which however declined to 13 percent in the coming two years, that was an encouragement for the banking sector. The growth of an economy cannot be assumed without the presence of a sound financial sector, and one of its many uses include getting an idea of the economy's performance. The major focus of this paper is to view the determinants of these non-performing loans: loans that are more than 90 days past due (NPLs), in Pakistan's banking sector and investigate the bank specific and macroeconomic variables.

The banking sector can deteriorate due to managerial issues, low capital adequacy ratios and poor asset quality. Non-performing assets is also the single largest cause of irritation of the banking sectors (Tiwari, Sontakke, \& Wardha, 2013). The assets deterioration is a serious problem unless the bank is efficient enough to recognize the problem before hand and handle it right away. This is one of the common factors which leads to bank failure. Poor asset quality leads to nonperforming loans that can seriously damage a banks' financial position having an adverse effect on bank's operations (Epure, \& Lafuente, 2015). Since its one of the major issues, its origin and cause must be taken into consideration. Different economies have their own reason for bank failure and a rise in non-performing loans. The reason may be situational factors such as the economic conditions or the bank level factors.

NPLs affect the liquidity and the profitability of the bank which is one of the major components of the overall bank performance. The rise in NPLs leads to the diminishing income in the economy. Non-performing loans should be given thorough consideration due its effect on the sustenance of the bank and survival of the economy. Mismatch of maturities between asset and liability create liquidity risk for the banks that deteriorate bank`s overall credit rating including its image (Badar \& Javed, 2013). 
NPL's have led to many problems in the financial sectors of the developing countries including Pakistan. Along with economic growth, increasing NPL's also effect the banking sectors. Kaminsky, \& Reinhart (1999) state that the rising trend of non-performing loans in any economy indicates financial crisis. Therefore, the main objective is to examine the bank specific and macroeconomic factors of non-performing loans for Pakistan's banking sector. We aim to explore the relationship of two new variables namely output gap and weighted maturity with the nonperforming loans.

\section{Literature review}

A plethora of studies are conducted on non-performing loans due to its importance on the banking sector and financial sector. NPLs are determined by three different categories namely bank specific factors, macroeconomic factors, and the regulatory framework. Bank specific factors include lagged NPLs, Loans to total assets ratio, weighted average lending rate and credit policy, credit deposit ratio, total assets, return on equity, return on assets are important bank specific factors and macroeconomic factors are real GDP per capita, interest rate, inflation, unemployment rate, real GDP growth, nominal exchange rate (NEER), harmonized index of consumer prices, share prices index and the 3-month money market interest rate. The relationship between these factors is discussed in the context of the available literature as follows.

Bad luck hypothesis by Berger and DeYoung (1997) states that events outside the control of banks lead to an increase in problem causing loan default. Loans that default cause banks to get involved in additional managerial effort to deal with the problem loans which lead to extra operating costs. Thus, under bad luck hypothesis, decreased measure cost efficiency leads to increases in nonperforming loans. Bad management hypothesis by Berger and DeYoung (1997) states that poor management at the senior level leads to low measured cost efficiency. Low cost efficiency is reflected in inefficient monitoring and poor control of operating expenses. It is not common for managers in these banks to practice adequate loan underwriting and therefore come under bad managers. Hence high numbers of nonperforming loans come about due to the practice of poor underwriting and monitoring as well as low cost efficiency. Both bad management and bad luck hypothesis give similar predictions related to the negative association of nonperforming loans with cost efficiency. Under the skimping hypothesis Berger and DeYoung (1997) the question in context is the exchange between the expected loan performance problems in the future and short 
lived operating costs. Banks bear the burden of skimping on resources devoted towards monitoring loans, underwriting and are ready to face the consequences of default on loans and possible problems in the future.

Extensive literature is available internationally on NPLs and its determinants following the financial crisis 2007-2008. Škarica (2014), explains how financial crisis has left a stream of high level of NPLs in the Central and eastern European countries (CEE) region. In the CEE region countries such as Bulgaria, Romania, Latvia, and Croatia had NPL ratios of 16.87\%, 14.3\%, $17.23 \%$ and $12.27 \%$ by the end of 2011 . The paper carries out study on the 7 countries and the data are collected from the central banks' quarterly financial stability reports for the period 20072012. The authors take ratio of NPLs to total (gross) loans as the dependent variable and explore the correlation between NPLs series and financial stability indicator (FSI) data and the macroeconomic variables included unemployment rate, real GDP growth nominal exchange rate (NEER), harmonized index of consumer prices, share prices index and the 3-month money market interest rate. To analyze the impact of macroeconomic and financial variables on the bank asset quality panel data technique is employed with fixed effects to control for time constant and unobserved heterogeneity across countries. The paper concludes that from amongst the determinants of NPLs the real GDP growth is the main driver of the high NPL ratio in the CEE countries. A cross country analysis for the period of 2003-2011 for the Central and Eastern European countries by Moinescu (2012) also confirms GDP growth to be an important variable explaining pattern of NPLs among CEE economies. Moreover, the findings prove an influence of short run economic performance on the ration dynamics of NPLS across CEE banking system.

Dimitrios, Helen, \& Mike (2016) explore the main determinants of nonperforming loans in Euro area banking system using GMM technique for the period 1990-1-2015-2. While studying the bank specific variables only, they find a significant relationship between loan to deposit ratio and NPLs. The lagged affect contributes significantly as well. The results do not support the moral hazard hypothesis. Related to managerial efficiency of the banks, ROE and its lagged effect are significant determinants of NPLs which supports the bad management hypothesis. Rajha (2016) analyses the Jordanian banking sector using panel data of 12 banks over the five years period. Bank specific factors include lagged NPLs, loan to asset ratio, bank size, capital adequacy ratio, leverage ratio, liquidity ratio, return on equity, return on asset, net profit before taxes and after taxes, and interest 
margin/ gross income. Macroeconomic factors include lending rate, inflation rate, economic growth, and global financial crisis. Panel data regression results indicate that lagged NPLs, loans to assets show positive and significant effect whereas size, lending rate has positive but insignificant impact. On the other hand, growth and inflation has negative and significant impact on non-performing loans.

Financial crisis of 2007-2008 triggered several studies to assess the determinants of financial distress in large financial institution. One such study is carried out by Zhang et. al. (2016). The study utilizes a sample of 629 BHCs using quarterly data for the period 2003Q1- 2013Q4 to assess the impact of various factors on the financial distress measured by the default risk in the U.S BHCs. The sample was divided in three periods before the crisis 2003Q1-2007Q2, during the crisis 2007Q3-2009Q4 and after the crisis 2010Q1-2013Q4. Housing Price Index (HPI): the distance to default (DD) and the Z-Score are the important factors determining the financial distress. BHCs credit risk is largely determined by the non-performing loan ratio. The hypothesis development for risk characteristics proves that non-performing loans are negatively related to the Z-Score and the DD of BHCs. According to Bennett \& Unal (2015) higher levels of non-performing assets ratio are inversely related with the DD measure. Nonperforming loan ratios are therefore the most important indicator of insolvency risk that has an important implication for the banks in the sense of improving their asset quality and internal functioning to escape the default risk.

Beck, Jakubik \& Piloiu (2015) explore the key determinants of Non-Performing Loans by empirically analyzing the global sample of 75 countries. Apart from the standard factors determining the bank asset, economic activity, they claim that exchange rate depreciation and widespread currency mismatch are associated with low bank asset quality and drop in share price leads to a rise in the growth of the NPLs. In the case of currency depreciation, NPLs increase due to the negative balance sheet effects however through an increase in the export volume via improvement in the financial position of the corporate sector, NPLs decrease as well. A rise in the debt servicing cost of various borrowers with different contracts affected NPLs in the case of lending interest rates. During the crisis of 2009-2010 the largest factor responsible for the deterioration of the bank's assets was the economic activity. Countries with inflation targeting were able to override the rise in NPLs through a cutoff in interest rates but economies with insufficient foreign exchange reserves faced currency depreciation. Countries with large stock 
market appeared to have economic significance of the share price decline for bank asset quality in contrast to economies with relatively moderate size of stock market.

Saba, Kouser, \& Azeem (2012) research the affectability of the macroeconomic variables on nonperforming loans in the United States of America for the period 1984-2010. A strong relationship is found between NPLs and total loans, interest rate and real GDP per capita. Uneconomic use of loans coupled with low per capita and high interest rate cause bad debts to occur reflected in the low repaying capacity of debtors. A panel data approach investigating the relationship between NPLs and ownership structure in Taiwan firms by Hu et al., (2004) covering the period between 1996-1999 reveals that there exists a negative relationship between NPLs and bank sizes. Fofack (2005) uses a pseudo panel and causality approach to examine non-performing loans in SubSaharan Africa for the period of 1993-2002 and finds out that variables such as real exchange rate, real interest rate, economic growth, inter-bank loans are main determinants of NPLs in Africa. The study also establishes that African economies are exposed to unprecedented and external shocks. Danisman (2018) examines the factors determining NPLs through financial statements of firms in turkey using yearly data of both listed Turkish financial firms and 27 non-commercial firms during the period of 2007-2015. The results of the dynamic panel data estimation (GMM estimations) identifies profitability, capital adequacy and bank size to have negative effect on NPL and supported the notion of higher the profitability of bank, lower the probability of NPLs. Similarly, findings of Kingu et al., (2018) indicate a negative relationship between high capital ratio, loan to asset ratio and asset growth with NPLs based on 16 Tanzanian commercial firm's data for the period of 2007-2015. The study also concludes a positive relationship between cost of inefficiency and NPLs. Swamy (2012) uses panel data approach on the Indian banking sector for the period 1997-2009 and suggests that ROA and Loan to deposit ratio have significant positive effect on nonperforming loans while factors such as inflation, real GDP growth, savings growth, bank lending have no significant impact on nonperforming loans. Another study by Ouhibi \& Hammami (2015) on six Southern Mediterranean countries (Egypt, Turkey, Lebanon, Morocco, Tunisia and Jordan) for the period 2002-12 shows that nominal exchange rate is positively associated with NPLs while gross capital formation and consumer price index has a significant negative impact on nonperforming loans. In a similar vein of research, Mileris (2012) finds a strong association between non-performing loans and the wider macroeconomic environment, in particular, impact of interest rates and unemployment rates on NPLs. 
Makri \& Papadatos (2014) analyze the factors affecting NPL for the eurozone's banking sector taking into account the both bank specific factors (lagged rate of non-performing loans, ROE and capital adequacy ratio) and macroeconomic factors (annual percentage growth rate of GDP, Public debt, unemployment). The study reveals statistically significant positive relationship between NPL and public debt, unemployment rate and lagged NPL value while a statistical negative relationship is observed for ROE and NPLs. Using a sample of 46 banks from twelve countries in Middle East and North Africa for the period of 2002-2006, Boudriga et al., (2010) analyze institutional environmental factors, business, and bank-specific factors impact on non-performing loans. The findings highlights the important role of institutional environment for enhancing credit quality while the results showed that return on assets and credit growth have a negative significant impact on non-performing loans; loan loss provision and capital adequacy have a significant positive influence on NPLs.

Nkusu (2011) examines the link between non-performing loans and macroeconomic performance based on a sample of 27 advanced economies for the period of 1998-2009 and finds out that poor macroeconomic performance (i.e. higher unemployment, falling asset prices and low GDP growth) translates into increased nonperforming loans in advanced economies. Evidence from 25 emerging countries (De Bock and Demyanets, 2012) confirms exchange rates, GDP growth rate and loan growth to be important factors determining NPLs. Results from the dynamic panel data examining determinants of non-performing loans in 15 transition economies for the period 19942009 show a negative significant impact of GDP growth and inflation on non-performing loans while competition in the banking sector has a positive significant impact on NPLs. The findings also point to a positive coefficient of lagged non- performing loans. A Systematic literature by Manz (2019) reviews and examines determinants of NPL in context of bank financial performance indicators, macroeconomic factors, and loan characteristics for period 1987-2017 and reveals the various findings and diverging views on the determinants of NPLs. He stresses on the need for a more in-depth understanding of NPLs and empirical research surrounding it.

Jameel (2014) investigates the effect of bank specific factors critical to bank sectors on the nonperforming loan of the bank. The study utilizes data from Pakistani commercial banks for 200011 period. Gross domestic product (GDP), weighted average lending's rate, capital adequacy ratio, and credit deposit ratio are the important factors associated with NPLs in Pakistan. Furthermore, 
Ahmad \& Bashir (2013) highlight the importance of macroeconomic variables such as foreign direct investment (FDI), annual growth in GDP, exchange rate, unemployment rate, broad money supply, inflation rate, exports, industrial production and CPI in context of NPLs in Pakistan. Ahmad \& Bashir (2013) explore the twenty two years banking sector data of Pakistan to assess the relationship between nonperforming loans and macroeconomic factors. The list of explanatory variables includes foreign direct investment (FDI), annual growth in GDP, exchange rate, unemployment rate, broad money supply, inflation rate, exports, industrial production, and CPI for the period 1990-2000. All the macroeconomic variables are found to be correlated significantly with NPLs.

On balance, literature highlights both bank specific and macroeconomic variables as drivers of non-performing loans. Internationalization and deregulation have created an environment of competition among the banks. Subsequently, credit risk has increased due to the relaxation in borrowing criteria leading to higher levels of NPLs which may put pressure on the income statement of banks due to higher provisions causing a liquidity problem for banks.

\section{Data \& Methodology}

This study utilizes various data sources including Economic Survey of Pakistan, State Bank of Pakistan's database, annual financial reports of individual banks to collect the data on nonperforming loans, capital adequacy ratio, total assets, interest rate, output gap, weighted maturity and market capitalization for 21 banks in Pakistan for 2006-16 period. The output gap is computed from GDP data and weighted maturity from individual bank specific statistics.

We choose panel data modelling for empirical estimation to cater for individual heterogeneity, collinearity, and to reduce the biases resulting from aggregation over firms (Baltagi, 2008).

$$
N P L_{i t}=\alpha+N P L_{i t-1}+X_{i t} \beta+u_{i t} \ldots \ldots
$$

with $u_{i t}=\mu_{i}+\varepsilon_{i t}$

where $i \& t$ denote banks and time respectively, $\alpha$ is a scalar and $\beta$ is a $K x 1$ vector of coefficients and $X_{i t}$ is a matrix of bank specific \& macroeconomic covariates for NPLs. The unobservable individual-specific effects are denoted by $\mu_{i}$ and $\varepsilon_{i t}$ is the disturbance term. 
Panel models that do not cater for cross-sectional dependency may lead to misleading inferences (Baltagi, 2008). To test the null hypothesis of no cross-sectional dependence, we call in the crosssectional dependence (CD) test proposed by Pesaran.

The null hypothesis of no cross-sectional dependence can be stated as correlation among the innovations of different banks.

$$
H_{0}: \rho_{i j}=\operatorname{corr}\left(u_{i t}, u_{j t}\right)=0 \text { for } i \neq j
$$

where $u_{i t}$ is the error term from equation (1) for bank $i$ and $u_{j t}$ is the disturbance term of bank $j$. Pesaran suggests a simple test of error cross-section dependence in panel with short $\mathrm{T}$ and large $\mathrm{N}$ as follows:

$$
C D=\sqrt{\frac{2 T}{N(N-1)}}\left(\sum_{i=1}^{N-1} \sum_{j=i+1}^{N} \widehat{\rho_{l j}}\right.
$$

under the null hypothesis of no cross-sectional dependence, CD test follows the standard normal distribution i.e. $\mathrm{CD} \rightarrow \mathrm{N}(0,1)$.

Based on the outcome of cross-sectional dependence test, ADF-Fisher test is used to explore the stochastic properties of our data. The Hausman test is applied to choose between the random vs. fixed effect models.

For the linear model as in eq. (1), we have the two estimators for $\beta: b_{0} \& b_{1}$. Under the null hypothesis, both the estimators are consistent but $b_{1}$ is efficient under the space of estimators containing $b_{0}$ however, under the alternative hypothesis $b_{0}$ is consistent whereas $b_{1}$ is inconsistent. The Wu-Husaman statistic is given below:

$$
H=\left(b_{1}-b_{0}\right)^{\prime}\left(\left(\operatorname{var}\left(\left(b_{1}\right)-\operatorname{var}\left(b_{0}\right)\right)^{-1}\left(b_{1}-b_{0}\right)\right.\right.
$$

under the null hypothesis, this statistics follows the Chi-square distribution asymptotically with degrees of freedom equal to the rank of the matrix: $\left(\operatorname{var}\left(\left(b_{1}\right)-\operatorname{var}\left(b_{0}\right)\right.\right.$.

\section{Results \& Discussion}

First step in panel data modeling is testing the cross sectional dependence. For short T (time) and large N (cross sections), Pesaran's cross-sectional dependence (CD) test is employed and there is 
enough evidence to reject the null hypothesis of no cross-sectional dependence (CD value $=43.51$ $\&$ p-value=0.0000). Under cross-sectional dependence, literature provide an appropriate option for testing the null hypothesis of unit root in the form of ADF-Fisher test for panel data. The unit root hypothesis testing results summarized in table 1 are indicative of the fact that all variables under consideration are integrated of order one i.e. I(1).

To choose between the fixed and random affect models, we call in the Hausman test. The Hausman statistic does not provide enough evidence to reject random effect model in favor of fixed effect model $\left(\chi^{2}=9.54, p\right.$-value=0.2144). Thus, we employ random effect model to estimate eq. (1) for overall sample of 21 banks in Pakistan and separately for commercial banks in Pakistan (table 2) to identify the leading determinants of nonperforming loans for the period 2006-16.

Lagged nonperforming loans turn out to be the significant determinant of NPLs for the entire sample and for commercial banks both. This finding is in line with the relevant literature (e.g. De Bock \& Demyanets, 2012). Bank size, proxied by total assets of individual banks, positively contributes to nonperforming loans in Pakistan both for overall sample and commercial banks which corroborates with the findings in Khemraj \& Pasha (2009). Generally, it is argued in the literature that larger banks tend to be ineffective in screening riskier loan in comparison to their smaller counterpart and therefore more default on efficiency grounds as compared to small banks which tends to be risk averse. It may also be argued that larger the bank, larger the absolute amount of loans and hence larger the absolute value of defaults.

Table 1: ADF-Fisher test

\begin{tabular}{llll}
\hline Variable & Method & At Level & At First Difference \\
\hline Non-performing loans & ADF-fisher chi-square & 0.092 & 0.000 \\
& ADF- choi z stats & 0.076 & 0.000 \\
& & & \\
Capital adequacy ratio & ADF-fisher chi-square & 0.081 & 0.000 \\
& ADF- choi z stats & 0.066 & 0.000 \\
Weighted maturity & ADF-fisher chi-square & 0.069 & 0.000 \\
& ADF- choi z stats & 0.059 & 0.000 \\
Output gap & ADF-fisher chi-square & 0.124 & 0.006 \\
& ADF- choi z stats & 0.070 & 0.000 \\
Market capitalization & ADF-fisher chi-square & 0.087 & 0.000 \\
& & 0.079 & 0.000 \\
\hline
\end{tabular}


ADF- choi z stats

Interest rate

ADF-fisher chi-square $\quad 0.095 \quad 0.000$

ADF- choi z stats

0.058

0.000

Total asset

ADF-fisher chi-square

0.259

0.004

ADF- choi z stats

0.721

0.000

Table 2: Random Effect Model Results

\begin{tabular}{lcccc}
\hline & All Banks & All Banks & Commercial Banks & Commercial Banks \\
\hline Variable & Coefficient & Coefficient & & Coefficient \\
\hline NPLs(-1) & $0.80^{*}$ & -- & $0.79 *$ & -- \\
CAR & $-0.013^{*}$ & $-0.03^{*}$ & $-0.011^{*}$ & $-0.28^{*}$ \\
CAP & $-0.04^{* *}$ & 0.04 & $-0.038^{* *}$ & $-0.09 * *$ \\
WM & -0.025 & 0.011 & 0.013 & 0.012 \\
OG & $6.15^{*}$ & $3.80^{*}$ & $4.70^{* *}$ & $4.50^{*}$ \\
TA & $0.14^{*}$ & $0.98^{*}$ & $0.15^{*}$ & $1.08^{*}$ \\
IR & $0.06^{*}$ & -0.02 & $0.05^{*}$ & $0.06^{* *}$ \\
Constant & $-1.60^{*}$ & $-2.86^{*}$ & $-1.69^{*}$ & $2.21^{*}$ \\
\hline
\end{tabular}

Note: $* \& * *$ represent significance at $1 \% \& 5 \%$ respectively. Nonperforming loans (NPLs), Capital adequacy ratio (CAR), market capitalization (CAP), weighted maturity (WM), output gap (OG), total assets (TA), \& interest rate (IR).

This study introduces output gap to capture the business cycle and potential growth of an economy. Output gap posits the away movements from potential growth of an economy which explains the positive and significant relationship with NPLs. Inefficient recovery during the recessionary period increases the nonperforming loans. In other words, an economy in the contractionary phase of the business cycle is observed to have more loan default than in expansionary phase of the business cycle.

The interest rate which is also the lending rate has significant impact on NPLs, which means lending rate does affect the ability of borrowers in repaying the loans. In case of commercial banks, interest rate has a significant positive effect on non-performing loans as well. Increase in interest rates makes savings attractive and lowers income resulting in possible loan defaults and therefore 
a positive association is observed. Manz (2019) asserts that interest rate increases the cost of borrowing and borrower chooses to increase the loan period and sometimes it becomes so long that the borrower becomes incapable of repaying and hence defaults.

Capital adequacy ratio (CAR) is used to promote stability in the financial system and to protect the depositors. A bank with a high proportion of funding to resources, all else equal to, is more ready to withstand a sudden misfortune than a bank with a low capital-asset ratio. Thus, such a bank is more averse to be tossed into indebtedness or subject to a run. This result is consistent with the findings in Makri, Tsagkanos, \& Bellas (2014), Danisman (2018), and Kingu et. al. (2018). This study establishes a negative relation between market capitalization (CAP) and nonperforming loans which is consistent with the moral hazard hypothesis which argues that low capitalization increases the riskiness of banks (Berger \& De Young, 1997). Market capitalization represents the market activity and higher the market capitalization higher will be the market activity resulting in more business possibilities. Thus, reduces the possibility of default.

Weighted maturity is treated as a dummy and it takes the value 1 if the loan maturity period is 0 2 years else zero value is assigned. Short run loans fall in the category of 0-2 years period while the long run comprises of all loans greater than 2 years. Results are indicative of the fact that NPLs in Pakistan do not depend their maturity.

\section{Conclusion}

Nonperforming loans (NPLs) have led to many problems in the financial sectors of the developing countries including Pakistan. The financial system of an economy is assumed to function smoothly. Most of the macroeconomic theories therefore presume its smooth functioning to the extent of eliminating its risk during financial consideration. The credit crunch 2007-2008 has captured the attention of the wider economic units. Twenty years down the lane the severe repercussion of what is called the worst financial crisis have shed light to the idea that worsening market conditions, declining asset prices and mounting debt burdens in the financial market are more than just indication of an economy in trouble rather these condition can themselves play a pivotal role in depressing real economic activity.

The study ascertains the determinants of nonperforming loans (NPLs) in Pakistan banking sector using a panel data of 21 banks for the period 2006-16. On balance, our findings corroborate with 
the previous literature on determinants of NPLs. We find, in particular for commercial banks, macro variables such as output gap and interest rate exert a strong influence. Bank specific variables like bank size, market capitalization, and capital adequacy ratio turned out to be the main drivers of NPLs. This is first empirical study that explores the role of weighted maturity (WM) in determining NPLs along with output gap as potential explanatory variables for banking sector in Pakistan. We could not establish any association between WM and NPLs however, output gap significantly impacts the NPLs.

\section{References}

1. Ahmad, F., \& Bashir, T. (2013). Explanatory Power of Macroeconomic Variables as Determinants of Non-Performing Loans: Evidence from Pakistan. World Applied Sciences Journal, 22(2), 243-255.

2. Badar, M., \& Javid, A. Y. (2013). Impact of macroeconomic forces on nonperforming loans: An empirical study of commercial banks in Pakistan. wseas Transactions on Business and Economics, 10(1), 40-48.

3. Baltagi, B. (2008). Econometric analysis of panel data. John Wiley \& Sons.

4. Beck, R., Jakubik, P., \& Piloiu, A. (2015). Key determinants of non-performing loans: new evidence from a global sample. Open Economies Review, 26(3), 525-550.

5. Bennett, R. L., Güntay, L., \& Unal, H. (2015). Inside debt, bank default risk, and performance during the crisis. Journal of Financial Intermediation, 24(4), 487-513.

6. Berger, A. \& DeYoung, R. (1997). Problem loans and cost efficiency in commercial banks. J. Banking Finance 21, 849-870.

7. Boudriga, A., Taktak, N.B. and Jellouli, S., 2010, September. Bank specific, business and institutional environment determinants of banks nonperforming loans: evidence from mena countries. In Economic Research Forum, Working Paper (Vol. 547, pp. 1-28).

8. Danişman, G.Ö., 2018. Determinants of Bank Stability: A Financial Statement Analysis of Turkish Banks 1. Sosyoekonomi, 26(38), pp.87-103.

9. De Bock, R. and Demyanets, M.A., 2012. Bank asset quality in emerging markets: Determinants and spillovers (No. 12-71). International Monetary Fund. 
10. Dimitrios, A., Helen, L., \& Mike, T. (2016). Determinants of non-performing loans: Evidence from Euro-area countries. Finance research letters, 18, 116-119.

11. Epure, M., \& Lafuente, E. (2015). Monitoring bank performance in the presence of risk. Journal of Productivity Analysis, 44(3), 265-281.

12. Fofack, H.L., 2005. Nonperforming loans in Sub-Saharan Africa: causal analysis and macroeconomic implications. The World Bank.

13. HU, J.L., Li, Y., \& CHIU, Y.H., 2004. Ownership and nonperforming loans: Evidence from Taiwan's banks. The Developing Economies, 42(3), pp.405-420.

14. Jameel, K. (2014). Crucial Factors of Nonperforming Loans Evidence from Pakistani Banking Sector.

15. Kaminsky, G. L., \& Reinhart, C. M. (1999). The twin crises: the causes of banking and balance-of-payments problems. American economic review, 89(3), 473-500.

16. Khemraj, T., \& Pasha, S. (2009). The determinants of non-performing loans: an econometric case study of Guyana.

17. Kingu, P. S., Macha, S., \& Gwahula, R. (2018). Impact of non-performing loans on bank's profitability: Empirical evidence from commercial banks in Tanzania. International Journal of Scientific Research and Management, 6(01).

18. Makri, V. \& Papadatos, K., 2014. How accounting information and macroeconomic environment determine credit risk? Evidence from Greece. International Journal of Economic Sciences and Applied Research, 7(1).

19. Makri, V., Tsagkanos, A., \& Bellas, A. (2014). Determinants of non-performing loans: The case of Eurozone. Panoeconomicus, 61(2), 193-206.

20. Manz, F. (2019). Determinants of non-performing loans: What do we know? A systematic review and avenues for future research. Management Review Quarterly, 69(4), 351-389.

21. Mileris, R., 2012. The Effects of Macroeconomic Conditions on Loan Portfolio Credit Risk and Banking System Interest Income. Ekonomika, 91(3), pp.85-100. 
22. Moinescu, B.G., 2012. Determinants of nonperforming loans in Central and Eastern European Countries: Macroeconomic indicators and credit discipline. Review of Economic and Business Studies, (10), pp.47-58.

23. Nkusu, M.M., 2011. Nonperforming loans and macrofinancial vulnerabilities in advanced economies (No. 11-161). International Monetary Fund.

24. Ouhibi, S. and Hammami, S., 2015. Determinants of nonperforming loans in the Southern Mediterranean countries. International Journal of Accounting and Economics Studies, 3(1), pp.50-53.

25. Rajha, K. S. (2016). Determinants of Non-Performing Loans: Evidence from the Jordanian Banking Sector. Journal of Finance, 4(1), 125-136.

26. Saba, I., Kouser, R., \& Azeem, M. (2012). Determinants of Non-Performing Loans: Case of US Banking Sector. The Romanian Economic Journal, 44(6), 125-136.

27. Škarica, B. (2014). Determinants of non-performing loans in Central and Eastern European countries. Financial theory and practice, 38(1), 37-59.

28. Swamy, Vighneswara. "Impact of macroeconomic and endogenous factors on nonperforming bank assets." Available at SSRN 2060753 (2012).

29. Tiwari, C. K., Sontakke, R., \& Wardha, P. (2013). Non-Performing Assets-A cause of Concern for Banks. ASM's International E-Journal Ongoing Research in Management and IT, INCON, 8, 1-6.

30. Zhang, D., Cai, J., Dickinson, D. G., \& Kutan, A. M. (2016). Non-performing loans, moral hazard and regulation of the Chinese commercial banking system. Journal of Banking \& finance, 63, 48-60. 